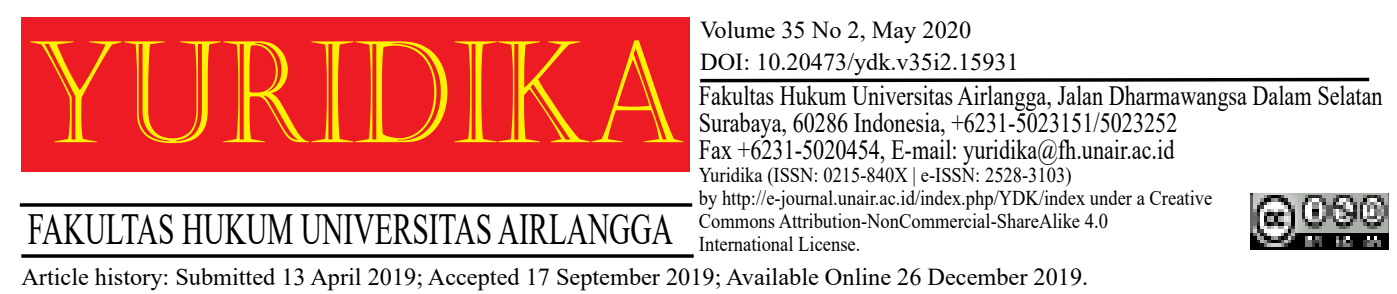

\title{
Analysis on Non Muslim Heir Position Towards the Inheritance of Muslim Testator in Indonesia
}

\author{
Tonic Tangkau, Prawitra Thalib, Daniel Julian Tangkau, Xavier Nugraha \\ and Windy Agustin \\ tonictangkau@outlook.com \\ Law \& Mediation Office of Tonic Tangkau \& Partners
}

\begin{abstract}
Article 171 section c the Compilation of Islamic Law which was ratified through the Presidential Instruction of the Republic of Indonesia Number 1 of 1991 stressed that one of the conditions for heirs in Islamic inheritance law is Mulsim. In its development, the requirement of the Islamic religious obligation is deemed not to provide justice, this can be seen from the many complaints filed by the community to the court. Based on this background, the formulation of the problem in this study is Firstly position of Non-Muslim Inheritance of Islamic Inheritance Inheritance according to positive law in Indonesia Secondly, to find out the position of Non-Muslim Inheritance Against Islamic Inheritance Inheritance from various court decisions in Indonesia. This research is a juridical research, with a statutory, conceptual, and case approach. The results of this study indicate, that First, according to positive law in Indonesia, Non-Muslim Heirs are not entitled to Islamic Inheritance. Secondly, in its development, to fulfill the sense of justice in the community, the judge in Indonesia, decided that the Non-Muslim heirs, although not entitled to become heirs, were still entitled to the inheritance of the Islamic heirs through the obligatory wills. This can be seen from the various court decisions that exist, such as Supreme Court Decision Number 368 K/AG/1995, Supreme Court Decision Number 51 K/AG/1999, Supreme Court Decision Number 16 K/AG/2010, and Supreme Court Decision No. $331 \mathrm{~K} / \mathrm{Ag} / 2018$
\end{abstract}

Keywords: Inheritance; Moslem Heir; Non Moslem Heir; Obligatory Bequest.

\section{Introduction}

In the words of Satjipto Rahardjo, a legal event is all matters/issue that moves the rule of law therefore it effectively shows its potential to regulate. ${ }^{1}$ Satjipto Rahardjo further explained that a legal event is an event in human life that drives

\footnotetext{
1 Satjipto Rahardjo, Ilmu Hukum (Citra Aditya Bakti 2006).[35].
} 
a certain legal regulation, hence the provisions contained therein are then realized. Generally, in a span of human life, there are three legal events experienced by humans, namely birth then followed by marriage and lastly with death. ${ }^{2}$ Indeed, there are times when people are unable to carry out one of these legal events in their lives, such as marriage, but these people will definitely experience the two other legal events, which is birth and death.

As we know, one of the legal events which surely will be experienced by humans is death. Due to the fact that human life must end with death, even arguably death is a right for every individual human (inna al-maut haqq). Therefore, death belongs to the category of natural law (sunnatullah), and it is certain that they will sooner or later experience death. This is in accordance with the Q.S. al-'Ankabut: 87 and al-Nahl: 61, which states "Kull nafs zaiqat al-maut summa ilaina turja'un".

Because death is a legal event, there are, of couse legal consequences for the event. The legal consequences of the death event for the dead person are all their rights and obligations expire, and even automatically move to the heirs who have the right to inherit it (zaw al-furud), especially when it comes to the assets left (altirkah), both in the form of movable objects such as cars, motorcycles and others. ${ }^{3}$

For Muslims, the distribution of inheritance is technically regulated in fara'id science, which includes, among others: ${ }^{4}$

1. inheritance system (nizam al-irts);

2. those who are entitled to inherit it (al-warits);

3. the level of inheritance that will be received by each heir (al-furud almuqaddarah);

4. property left by the testator (almuwarrits); and

5. others, such as people who are prevented from inheritance rights (alhijab), or people who are prohibited from receiving their inheritance rights (mawani 'alirts).

Normatively, regarding the distribution of inheritance, it is regulated in the

\footnotetext{
2 Mulyadi, 'Kedudukan Hukum Anak Luar Kawin Yang Diakui' (2016) 11 Cakrawala $<$ http://journal.ummgl.ac.id/index.php/cakrawala/article/view/103>.[93].

3 Maimun, 'Pembagian Hak Waris Terhadap Ahli Waris Beda Agama Melalui Wasiat Wajibah Dalam Perspektif Hukum Kewarisan Islam’ (2017) 9 Asas: Jurnal Hukum dan Ekonomi Islam. [1].

4 ibid.[2].
} 
Compilation of Islamic Law which was ratified through Presidential Instruction of the Republic of Indonesia Number 1 of 1991 concerning Compilation of Islamic Law. As with this inheritance law, it is regulated in Book II of the Compilation of Islamic Law, which is specifically regulated in 6 Chapters, which consists of Articles 171-1 214.

In the Book II of Compilation of Islamic Law, it begins with Chapter I which contains general provisions related to Islamic Inheritance Law. In Chapter I, there is Article 171 which contains general arrangements of Islamic Inheritance Law, one of which is the requirements for one to become heirs in Islamic Inheritance Law which explained in the following: ${ }^{5}$

1. Of blood relationship or marital relationship with the testator;

2. Muslim; and

3. Not hindered by the law to become heirs.

The three conditions are cumulative conditions. Therefore, if there is only one condition that is unable to be fulfilled, then that person will automatically not be able to become an heir.

Along with its development, the three cumulative conditions are no longer absolute. A dynamic and change in the sense of justice in the community arises for the requirements of the heirs, one of which is related to the issue of inheritance of different religions. The development of a justice paradigm in the community, leads to a sense of injustice for those who had good intentions by caring for the testator before dying, but did not receive any inheritance just due to religious differences.

This leads to the Supreme Court of the Republic of Indonesia to issue the Supreme Court Decree Number $331 \mathrm{~K} / \mathrm{Ag} / 2018$. Through this provision, the Supreme Court made a new breakthrough in the matter of inheritance of people with different religions. This breakthrough can be clearly seen from the decision that provides a loophole and opportunity for non-Muslims to be able to receive a share of the inheritance of the Muslims. These opportunities are not

\footnotetext{
5 Naskur, ‘Ahli Waris Dalam Kompilasi Hukum Islam’ (2008) 6 Al-Syirah.[4].
} 
provided in the form of pure inheritance practices, but of concepts or rules of the obligatory bequest. ${ }^{6}$

The mandatory will was originally a system applied in the Compilation of Islamic Law (KHI) to provide a portion of inheritance among the parties involved in family with adopted members. The application of the obligatory bequest system was in fact used by the Supreme Court of the Republic of Indonesia to provide part of inheritance to non-Muslim parties from Muslim parties. ${ }^{7}$

The obligatory bequest cases conducted by the Supreme Court for nonMuslim heirs, according to various groups, in a form of ijtihad as a legal discovery through sociological juridical methods, referring to Hazairin's view which takes Ibn Hazm's opinion and asserts that Islam is a religion that is rahmatan lil , alamin which upholds the principle of justice, the principle of certainty (absolutism), the principle of the individual and the principle of bilateral. ${ }^{8}$

The Supreme Court Decree Number $331 \mathrm{~K} / \mathrm{Ag} / 2018$ has justified the obligatory bequest of husbands of different religions. Uniquely, the legal considerations used by the decree, where the husband is of a different religion, but has good intentions to care for his wife until his death, makes the decision becomes a landmark decision as determined by the Supreme Court through the 2018 Annual Report published by the Supreme Court. Based on the background explained previously, this research tries to provide legal research with the formulation of the following problem. The position of heirs who are not Muslim, but who have made good intentions by caring for the testator prior to their death and Ratio Decedendi of the Supreme Court Judge in decision No. $331 \mathrm{~K} / \mathrm{Ag} / 2018$.

This is a study of legal argumentation by focusing on the main characteristics of examining a case accompanied by legal arguments/considerations made by law

6 Muhammad Rinaldi Arif, 'Pemberian Wasiat Wajibah Terhadap Ahli Waris Beda Agama (Kajian Perbandingan Hukum Antara Hukum Islam Dan Putusan Mahkamah Agung Nomor 368.K/ AG/1995) (2017)' (2AD) 2 De Legal Lata <http://jurnal.umsu.ac.id/index.php/delegalata/article/ view/1161>.[352].

7 Asep Saepuddin Jahar, Hukum Keluarga, Pidana Dan Bisnis (Prenada Media 2013).[94].

8 ibid. 
enforcers, as well as the interpretation behind the enforcement. ${ }^{9}$ This research was conducted with normative research. Normative research is research which puts the law as a building norm system, which consists of principles, norms, rules of legislation, court rulings, agreements and doctrines (teachings). ${ }^{10}$ This normative research is conducted through studying and analyzing the laws and regulations or other legal materials relating to heirs of different religions in Islamic Inheritance Law.

This study uses the statute approach,conceptual approach and case approach. The statute approach was carried out by examining all laws and regulations relating to the legal issues in question, hence the legis ratios, ontological basis and philosophical basis of the legislation can be determined. ${ }^{11}$ Analysis of the legislation studied is related to the heirs of different religions in the Islamic Inheritance Law. These regulations include the Presidential Instruction of the Republic of Indonesia Number 1 of 1991 concerning the Compilation of Islamic Law.

The case approach uses a judge's ruling as a source of legal material. The Judges' decision in this term are those of judges who have permanent legal force. ${ }^{12}$ When discussing court decisions as primary legal material it has been said that one that has the legal power is in the ratio decidendi, namely the legal reasons used by the judge in determining his/her decision (judge's consideration) as stipulated in the Decision of the Supreme Court No. $331 \mathrm{~K} / \mathrm{Ag} / 2018$.

The comparative approach is a type of approach that researchers compare with other countries and with events that have occurred in the country. For this reason, this is known as the 2 Comparative Approach; Macro Comparative Approach and the Micro Comparative Approach. ${ }^{13}$ In this study the approach applied is the micro

\footnotetext{
9 Xavier Nugraha, [et., al.]., 'Rekonstruksi Batas Usia Minimal PerkawinanSebagai Bentuk Perlindungan Hukum TerhadapPerempuan' (2019) 3 Lex Scientia Law Review.[43].

${ }^{10}$ Debri Liber Sonata, 'Metode Penelitian Hukum Normatif Dan Empiris: Karakteristik Khas Dari Metode Meneliti Hukum’ (8AD) 1 Fiat Justitia Jurnal Ilmu Hukum.[25].

${ }^{11}$ Mark Van Hoecke, 'Legal Doctrine: Which Method(s) for What Kind of Discipline?', Methodologies of legal research : which kind of method for what kind of discipline? (Hart Publishing 2011) <https://biblio.ugent.be/publication/1091776>.[16].

12 Oly Vina Agustine, 'Jurisprudence Enforceability on Judicial Review Authority in the Constitutional Court Decision’ (2018) 15 Jurnal Konstitusi.[644].

13 C.F.G Sunaryati, Penelitian Hukum Di Indonesia Pada Akhir Abad 20 (Alumni 2006).[139].
} 
comparative approach, which compares the principle of inheritance law in China with the principle of inheritance law in Indonesia.

\section{The State of Heirs of Different Religion with Good Intentions in Islamic Inheritance Law}

The word inheritance (Indonesian: waris) comes from Arabic word of"warasayarisu" which means to transfer someone's property to someone after death. ${ }^{14}$ While in the Quran there are many words of "warasa" found which means differently as replacing the position (QS. An-Naml (27): 16), giving or conferring (QS Az-Zumar (19): 74), and ones who received inheritance (QS Maryam (QS) 19): 6). Whereas al-miras according to the ulama's term 'is the transfer of ownership rights of the deceased to his/her heirs who are still alive whether in the form of property, land or else in the form of legal syar'i ownership. ${ }^{15}$

While inheritance (Al-miras) which is also referred to as faraidhl means a certain portion of inheritance as stipulated in the Nash(Sentences of Quran which contains direct command) Al-Quran and Hadith. ${ }^{16}$ From this basis it can be concluded that inheritance is the transfer of rights and obligations regarding the wealth of someone who has passed away to people who are still alive with the parts that have been specified in nash both in the Qoran and the Hadith. ${ }^{17}$ If we refer to Article 171 of the President Instruction of the Republic of Indonesia Number 1 of 1991 concerning Compilation of Islamic Law, Inheritance Law is a law that regulates the transfer of inheritance rights (tirkah) of the testator, determines who has the right to become heirs and how many shares or fair distribution.

If we take a look at Article 171 of the President Instruction of the Republic of Indonesia Number 1 of 1991 concerning the Compilation of Islamic Law, Testators are people who at the time of his/her death or who were declared deceased based

\footnotetext{
${ }^{14}$ M. Syafi'ie, 'Hak Non Muslim Terhadap Harta Waris' (2011) XI Al-Mawarid.[177].

15 ibid.

16 ibid.[178].

17 ibid.[179].
} 
on the decision of the Islamic Religious Court, which leaving heirs and inheritance. While the heir is a person who at the time of the testator's death has a blood relationship or marital relationship with the testator, is a Muslim and is not hindered by the cause of law to become an heir. Heirs according to Islamic law itself can be seen from 2 (two) aspects, namely in terms of the reasons a person can inherit one another and in terms of gender. ${ }^{18}$

In terms of causes for a person to pass inheritance to one another, then heirs according to Islam can be classified to: ${ }^{19}$

1. Sababiyah heirs.

Sababiyah's heirs are heirs who are entitled to a part of the inheritance due to the marriage relationship with the deceased. The marriage relationship occurs because of a contract which pronounced a man with a woman as husband and wife. Hence, the sababiyah heirs are husband and wife. If one of them dies, the other may inherit the inheritance. This has been explained in Q S An-Nisaa '(4): 12.

2. Nasabiyah heirs. Nasabiyah heirs are heirs who are entitled to obtain a part of the inheritance due to a nasab (offspring) relationship with the deceased person. Judging from the direction of nasab relationship, there are down, up and sideways lines, and the nasabiyah heirs are divided into three types, namely:

a. Furu 'al-Mayit, the child of the deceased. Nasab relationship between the heir and his descendants is reffered to a straight line down nasab relationship, ones who may reffered to be furu 'almayit are:

a) Male and Female offsprings. Allah SWT explains in His Word Q S AnNisaa '(4): 11. "Allah prescribed to you on (the distribution of heirlooms for) your children. namely: the share of a son is the same as the part for two daughters ... “

b) Male Grandchildre or great grandchildren or sons of sons and so on downward without daughters or female offsprings as according to the lafaz

\footnotetext{
${ }^{18}$ Firdaweri, 'Konsep Ahli Waris Menurut Islam Dan Adat' (2015) 7 ASAS.[3].

19 ibid.
} 
auladukum in Q S An-Nisaa (4): 11, may be used as an argument for this type of heir.

c) A granddaughter of a male offspring, or a daughter of a son. This is furthter explained by the hadith of the Prophet Muhammad as the following:

"From Ibn Mas'ud, the Prophet Muhammad had regulate about the portion of the daughter $1 / 2$, and for the daughter of the son $1 / 6$, and to fulfill the portion to be $2 / 3$. And the rest is for the sisters".

b. Ushul al-Mayit, Namely those who is partake the cause for the birth of the deceased (the testator). This nasab relationship according to the lineage is a straight up line. Ones included in this type of heirs are:

a) The father and mother of the. This is as explained by Allah SWT in His Word in Q S An-Nisaa '(4): 11.

"... and for the mother and father, for each of them one-sixth of the assets left, if the deceased has children; if the deceased has no children and is inherited by his mother (only), then the mother obatains a third of the part. ... "“

b) Shaheeh Grandfathers, Namely the father of the father, father of the father from the father onwards so on with no female in line. When interspersed by female lineage, this heir will be reffred to as Ghairu saheeh grandfather. The position of the saheeh grandfather as the heir will be explained in the following: “... From Sulaiman bin Yasar,: Umar bin Khathab determined ... the portion for the grandfather is one-sixth of the total".

c) Shahihah Grandmother, grandmother with nasab lineage uninterrupted by the grandfather. While the grandmother whose the nasab linage is interspersed with ghairu shaheeh grandfather is reffered to as Ghairu Saheeh Grandmother. This grandmother's position as heir is explained by the hadith of the Prophet (PBUH) in the following:

"As stated from Ibn Buraidah from his father that the Prophet (PBUH) set for the grandmother one-sixth part of the inheritance if not along with the mother."

As seen in terms of gender, the heirs are categorized into male heir and female heir. Male heirs are then devided again into 15 types of male family members. For 
female heirs there are 14 types of female family members. ${ }^{20}$

The explanation above explains the requirements for the heirs namely to own blood and or marriage relation. In the sense of heirs themselves, there are two other conditions, namely they must be Muslim and there is nothing to prevent them from obtaining the inheritance. All three are cumulative requirements to become an heir. If one is unfulfilled, then the right to become an heir will vanish. In the as-Sunnah stated by Imam al-Bukhari and Muslim, which states:

"Muslims have no right to inherit unbelievers (kafir), and unbelievers have no right to inherit Muslims (inherintance)". (Hadith by Al-Bukhari and Muslim). In the Hadith above, it is explained that only Muslim can become heirs to another muslim. Next, we take look in to the other aspects where there are no other conditions which prevent one for obtaining the inheritance, These conditions include: ${ }^{21}$

1. different religion between heirs and testators. The reason for this condition is the Prophet's hadith which teaches that Muslims do not have the right to inherit the wealth of the non-muslims which also do not have the right to inherit the wealth of Muslims;

2. murder. The Prophet's hadith teaches that murderers do not have the right to inherit the assets of the murdered/deceased. What is meant by killing is the intentional act of murder/killing which contains criminal elements.

Thus in instances where the heir is not a Muslim, it is certain that the heir cannot inherit the from a Muslim heir. The concept of non-Islamic religion is generally associated with the Kafir term. In the Qur'an itself the word Kafir is often found and placed as the center of evil and makes it the opposite of the word of faith or Iman which is the source of all goodness (Harifuddin Cawidu, 1991, P.18). The concept of kafir or ones with nonIslamic religion then becomes a barrier to the existence of inheritance rights for heirs as they do not meet the requirements as heirs. Which stimulates a form of discrimination against heirs of different religions. Ali Asgar Engineer argues that kafir conceptions are not merely speculative transdental but also socially reflective of humanity.

\footnotetext{
${ }^{20}$ ibid.

${ }^{21}$ Khisni, Hukum Waris Islam (Unissula Press 2013).[5].
} 
According to An-Na'im, the problem of discrimination against non-Muslims under sharia law can no longer be justified. He also stated that this was a form of violation of the enforcement of human rights, so as to create international conflict and war situations. Therefore, this act of discrimination is cosiderred as irrelevant to the present situation. Discrimination is fundamentally contrary to moral values and that sharia provisions should lean towards universal manner. In line An-Na'im, Asgar also argues that religious differences are not one to reduce the unity of humanity and also the value of justice in the society.

However in its development, it has been found several cases where the heirs who are not a Muslim are prohibited to receive inheritance. Several Supreme Court Jurisprudence states that religious differences do not cause the position of heirs to be lost, this is explained in the Supreme Court Decision Number 16 K/AG/2010 "To bestowed the position of a wife who is not a Muslim with the same position of a Muslim wife", The Supreme Court Decision Number 51 K/AG/1999 stated, "Heirs who are not Muslim may still inherit from the inheritance of their Muslim testatir, in this case the inheritance applies through obligatory bequest", and the Supreme Court of the Republic of Indonesia Decision Number 368 K/AG/1995 stated ; "The rights of children who convert (to other religions) has the same position with the rights of other children who are Muslim".

In the Supreme Court Decision Number $16 \mathrm{~K} / \mathrm{AG} / 2010$, the wife of the deceased testator, and is not of Muslim religion. In his consideration, the judge will not ignore the heir requirements as in Article 171 of the Compilation of Islamic Law. The judge stated that the marriage of the testator ad his wife has been going on for a long time, in this case is 18 years. Throughout their lives, the two had no children, and during that time the wife devoted herself to the testator. Thus, the judge believes that even though the wife is not a Muslim, she is worthy and only fair for her if she receive a share of the inheritance in the form of obligatory bequest.

Legal considerations used by the judges in deciding cases of inheritance of people with different religions are the opinions of Ulama/Clergy YusufAl-Qardhawi. According to the panel of judges that between the testator (Muslim) and his wife 
(non-Muslim) has lived in harmony, the non-Muslim wife is entitled to inheritance rights based on obligatory bequest.

In Islamic encyclopedia, obligatory bequest is also referred to as al-wasiyyah al -ajibah, a will/bequest intended for heirs or relatives who do not obtain part of the inheritance of the deceased person/testator. Meanwhile, according to Rahman, the obligatory bequest is an act of one's own will without coercion from other parties, even the authorities and judges have no right to force someone to give a will. ${ }^{22}$

The granting of inheritance rights based on obligatory bequest to nonMuslim heirs is one of the reforms of Islamic law in the field of inheritance in Indonesia. The legal reform was born (exist) from the results of ijtihad of the judges of the Supreme Court through examining, adjudicating and deciding the case of inheritance of family with different religions. Basically a judge may conduct ijtihad whilst deciding a case that does not yet have a rule of law which regulates the problem in question, but the judges who conducted ijihad may not conflict with the principles of the Qoran and the Hadith and the existing law.

Analysis of The Supreme Court Decision Number 331 K/Ag/2018:

\section{Implementation of the Socialist Morality Principle in Indonesia}

According to Nurul Qamar in his book the Comparison of the Law System and the Civil Law System and Common Law System, generally the law systems of different nations are divided into 2 (two), namely civil law systems and common law systems. There are three main characteristics of a country that adhere to the Civil Law system, namely. ${ }^{23}$

1. The existence of a codification system;

2. Judges are not bound by the precedent or doctrine of stare decicis, Hence the law becomes the main legal reference; and

3. The justice system is inquisitorial.

\footnotetext{
${ }^{22}$ Fatchur Rahman, Ilmu Waris (Alma'arif 1981).[62].

${ }^{23}$ Nurul Qamar, Perbandingan Sistem Hukum Dan Peradilan (Civil Law System and Common Law Systems) (Pustaka Refleksi 2010).[40].
} 
Meanwhile, the three characteristics of the common law system: ${ }^{24}$

1. Jurisprudence as the main source of law;

2. The adoption of the Stare Decicis Doctrine/Precedent System; and

3. Adversary System in the judicial process.

Based on the dichotomy of Nurul Qomar, we may found that Indonesia is a country that adopts the civil law system.

However, in its development this dichotomy is no longer relevant. This is due to the complexity of the problems and legal developments within the country, therefore this classification is no longer relevant. As seen from the fact that there is no country in the world that adopts a single legal system. For example, in the Netherlands which is said to be a civil law state, it turns out that it has applied case law in the hierarchy of its laws and regulations. ${ }^{25}$

Even though Indonesia is unlike the Netherlands to include case law in its legislation, case law also has its own position in the legal system in Indonesia. According to Shidarta, case law in Indonesia does not have binding legal force, as the jurisprudence originating from case law is persuasive (the persuasive force of precedent). ${ }^{26}$

Importantly, one the most persuasive decision in Indonesia is the landmark decision. Landmark decision is the decision issued by the highest court institution (in Indonesia for this context reffered to the Supreme Court or the Constitutional Court) to be acknowledge by the general public. The decision issued becomes the landmark decision, generally as the ratio decedendi applied by the judge in considering an existing dispute is deemed to be of very high quality. With the expectation that through the landmark decision of the highest court institution, it may become a reference for other judges.

\footnotetext{
${ }^{24}$ ibid.[48].

${ }_{25}$ A'an Effendi, 'Problematika Hierarki Peraturan Perundang-Undangan' (Gresnews, 2015) $<$ http://www.gresnews.com/berita/opini/101185-problematika-hierarki-peraturan-perundang-undangan/> accessed 20 October 2019.

${ }^{26}$ Shidarta, 'Yurisprudensi Dan Putusan Landmark' (Business Law Binus, 2018) <http://business-law.binus.ac.id/2018/07/07/yurisprudensi-dan-putusan-landmark/> accessed 20 October 2019.
} 
In 2018, the Supreme Court, through the 2018 Annual Report, announced that there were five landmark decisions, namely Decision Number 534 PK/Pdt/2018, Decision Number 2729 K/PID.SUS/2016, Decision Number 331 K/Ag/2018, Decision Number 343 K/Mil/2016, and Decision Number 232 K/TUN/2018. One of the landmark decisions is Decision Number $331 \mathrm{~K} / \mathrm{Ag} / 2018$ which has a new legal existance and rulings for Islamic inheritance law.

Citationes non coneantant priusquam exprimatur super qua re fieri debet citation, a postulate which means the use of jurisprudence will not be accepted until the relation between the case and the jurisprudence is explained. The depth of the meaning of this postulate is translated to the use of a previous judge's decision cannot be used as jurisprudence, prior to the ratio decedendi of a jurisprudence to be understood thoroughly. To fully understand the ratio decendendi of one decision, then of course to fully knowledgeable about the case of the position as asbabun nuzul from the decision.

Whereas, the summary of position cases from the Supreme Court Decision Number $331 \mathrm{~K} / \mathrm{Ag} / 2018$ are (Supreme Court, 2018, p.228):

1. That the marriage of Dr. Anita Nasution bint H. Amir Husin Nasution and Victor Sitorus bin L. Sitorus as quoted the Marriage Certificate No. 855/26/ XII/1999 issued by KUA(Office of Religous Affairs) of Pesanggrahan District;

2. That from the marriage of Dr. Anita Nasution bint H. Amir Husin Nasution with Victor Sitorus bin L. Sitorus (Defendant) did not bear any offsprings

3. That on Monday, August 26, 2008 Dr. Anita Nasution bint H.Amir Husin Nasution has passed away in Guangzou China;

4. That the late Dr. Anita Nasution left a heir of a husband named Victor Sitorus (Defendant) and her four siblings:

a. Arman Nasution bin H.Amir Husin Nasution (Plaintiff I);

b. Irwani Nasution bint H.Amir Husin Nasution (Plaintiff II);

c. Drs. H.Arlan Nasution bin H.Amir Husin Nasuton (Plaintiff III);

d. Iryani Nasution bint H.Amir Husin Nasution (Plaintiff IV);

e. H.Arwin Nasution bin H.Amin Husin Nasuton (Co-Defendant);

f. That Defendant Victor Sitorus has moved/returned to Christianity therefore becomes a preventive act for the Defendant to obtain inheritance from the 
deceased;

g. That in their marriage Dr. Anita Nasution and the Defendant have joint property/estate:

g. 1. A plot of land and residential building with an area of $+1200 \mathrm{M} 2$ located on Jl. Puyuh Tmur IX 6/10 Bintaro V RT.008 / RW.009 Jurang Mangu Timur Village Pondok Aren District South Tangerang City.

That the inheritance from the deceased is half of the joint assets as previously stated;

h. That the Plaintiffs have repeatedly requested the Defendant to complete the distribution of the assets by deliberation but the Defendant was not willing;

i. That the Plaintiffs demanded the Defendant to share the assets in accordance with the provisions of inheritance law based on faraidh;

From the summary of the position case, that Anita Nasution is a Muslim woman who has a husband named Victor Sitorus who at the time of marriage was also a Muslim. Due to her illness, Anita Nasution was brought by Victor Sitorus to seek treatment at Guangzhou. However, it turns out that Anita Nasution's disease could not be cured and passed away in Guangzhou. Another fact is that Anita Nasution had relatives, namely: Arman Nasution, Irwani Nasution, Iryani Nasution, Arlan Nasution, H. Arwin Nasution. After Anita Nasution passing, Victor Sitorus converted his religion to Christianity. This then prevented Victor Sitorus from obtaining inheritance from Anita Nasution estate.

In the Decision Level I, which is the Decision Number 2886/Pdt.G/2014/ PA.TGRS and Decision Level II, Decision Number 0078/Pdt.G/ 2017/PTA.Btn it is stated that although Victor Sitorus has caring for the testator(Anita) during her illness, but due to the fact that Victor Sitorus is a Christian, therefore he is not entitled to the estate. However, this was then corrected by the Supreme Court in the decision of the Supreme Court Number $331 \mathrm{~K} / \mathrm{Ag} / 2018$. The ratio decedendi used by the Supreme Court is: ${ }^{27}$

That through thorough observation of the relationship between the Cassation Appellant and the Testator during her lifetime which was harmonious, the Cassation Appellant accompanied and caring for the testator as a wife through joy and sorrow, even when the testator was suffering from her illnes, the Cassation Appelant

${ }^{27}$ Supreme Court, 2018.[228]. 
continued to care for her faithfully and was with her during medical treatment in China, then it is considered to be appropiate and fair for the Cassation Applicants who are non-Muslim to be given part of the inheritance in the form of obligatory bequest with the amount of $1 / 4$ (one fourth) of the inheritance/estate.

Based on the ratio decedendi reffered to by the Supreme Court, it is found that the judge saw the good deeds of Victor Sitorus as the husband of Anita Nasution which was manifested through his actions of patiently caring for Anita Nasution, and even accompanied her to seek treatment to China. Therefore, it is proper for Victor Nasution to receive inheritance share through obligatory bequest of $1 / 4$ (one quarter) of the total estate/inheritance.

The ratio decendendi which reffered by the Supreme Court is actually a manifestation of the socialist morality principle known in the inheritance law in China Generally, China's Inheritance Law is similar to many other countries in that the order of succession is based on blood and marital relationships, but China has also inserted an interesting principle in the Inheritance Law which can change the inheritance order. This principle is based on what the Chinese called the principle of 'socialist morality'. It brings into play, mixed with the degree of kinship, the concept of consideration and good faith.

The provision based on this principle in Chinese inhereitence law, such as Article 12 in Law of Succession of the People's Republic of China. According to article 12 Law of Succession of the People's Republic of China, a widowed daughter-in-law or son in-law, who has conducted the main obligation to support his or her father in-law or mother-in-law, shall be regarded as a successor first in order. The next article is article 13 Law of Succession of the People's Republic of China. According to article 13 Law of Succession of the People's Republic of China, the Inheritance Law also provides that a successor who had the ability to support the deceased but failed to do so could be given a smaller share or deprived of his or her share of the estate.

This principle even extends to a person with no blood or marital ties whatsoever with the deceased, even a neighbour. For example, there is a case in 
China which holds that the deceased's neighbour who has helped her for ten years was entitled to part of the estate to the exclusion of some of the deceased's children. Again, the case stresses the court's attempt to balance, socialist morality with the rights of relations by blood and by marriage.

\section{Conclusion}

Based on this study, it can be seen that previously heirs who were not Muslim were not heirs in Islamic inheritance law. This causes, that the heirs who are not Moslem at all are not entitled to inheritance. However, in its development, it can be seen, that although the Muslim heirs are not classified as heirs, they still obtain an inheritance. The inheritance obtained by the heirs who are not of Moslem religion is obtained through the obligatory bequest.

However, in its development, it can be seen, that although the Muslim heirs are not classified as heirs, they still obtain an inheritance. The inheritance obtained by the heirs who are not of Moslem religion is obtained through the obligatory bequest. Even though heirs who are not Muslim can obtain inheritance through obligatory bequest, it does not mean that every heir who is not Muslim can obtain assets through mandatory wills. Only heirs in good faith can obtain inheritance through compulsory wills. The good faith of the heirs who are not Muslim can be assessed from the actions of the heirs who care for the testator for life. This is following the principle of socialist morality.

The implementation of socialist morality in Indonesia can be seen from the landmark decision issued by the Supreme Court through the Decision of the Supreme Court Number $331 \mathrm{~K} / \mathrm{Ag} / 2018$. Through this decision, the Supreme Court applied the principle of socialiast morality, where although the heir is not a Muslim, if he/she has a good intention which is realized by caring for the testator until the testator's death, then he/she still has the right or eligable to inheritance through the obligatory bequest. 


\section{Bibliography}

A'an Effendi, 'Problematika Hierarki Peraturan Perundang-Undangan' (Gresnews, 2015) $\quad<$ http://www.gresnews.com/berita/opini/101185-problematikahierarki-peraturan-perundang-undangan/> accessed 20 October 2019.

Asep Saepuddin Jahar, Hukum Keluarga, Pidana Dan Bisnis (Prenada Media 2013).

C.F.G Sunaryati, Penelitian Hukum Di Indonesia Pada Akhir Abad 20 (Alumni 2006).

Debri Liber Sonata, 'Metode Penelitian Hukum Normatif Dan Empiris: Karakteristik Khas Dari Metode Meneliti Hukum’(8AD) 1 Fiat Justitia Jurnal Ilmu Hukum.

Fatchur Rahman, Ilmu Waris (Alma’arif 1981).

Firdaweri, 'Konsep Ahli Waris Menurut Islam Dan Adat' (2015) 7 ASAS.

Khisni, Hukum Waris Islam (Unissula Press 2013).

M. Syafi'ie, 'Hak Non Muslim Terhadap Harta Waris' (2011) XI Al-Mawarid.

Maimun, 'Pembagian Hak Waris Terhadap Ahli Waris Beda Agama Melalui Wasiat Wajibah Dalam Perspektif Hukum Kewarisan Islam’ (2017) 9 Asas: Jurnal Hukum dan Ekonomi Islam.

Mark Van Hoecke, 'Legal Doctrine: Which Method(s) for What Kind of Discipline?', Methodologies of legal research : which kind of method for what kind of discipline? (Hart Publishing 2011) < https://biblio.ugent.be/ publication/1091776>.

Muhammad Rinaldi Arif, 'Pemberian Wasiat Wajibah Terhadap Ahli Waris Beda Agama (Kajian Perbandingan Hukum Antara Hukum Islam Dan Putusan Mahkamah Agung Nomor 368.K/AG/1995) (2017)' (2AD) 2 De Legal Lata $<$ http://jurnal.umsu.ac.id/index.php/delegalata/article/view/1161>.

Mulyadi, 'Kedudukan Hukum Anak Luar Kawin Yang Diakui' (2016) 11 Cakrawala $<$ http://journal.ummgl.ac.id/index.php/cakrawala/article/view/103>.

Naskur, ‘Ahli Waris Dalam Kompilasi Hukum Islam’ (2008) 6 Al-Syirah.

Nurul Qamar, Perbandingan Sistem Hukum Dan Peradilan (Civil Law System and Common Law Systems) (Pustaka Refleksi 2010).

Oly Vina Agustine, 'Jurisprudence Enforceability on Judicial Review Authority in 
the Constitutional Court Decision’ (2018) 15 Jurnal Konstitusi.

Satjipto Rahardjo, Ilmu Hukum (Citra Aditya Bakti 2006).

Shidarta, 'Yurisprudensi Dan Putusan Landmark' (Business Law Binus, 2018) $<$ http://business-law.binus.ac.id/2018/07/07/yurisprudensi-dan-putusanlandmark/> accessed 20 October 2019.

Xavier Nugraha, [et., al.]. 'Rekonstruksi Batas Usia Minimal PerkawinanSebagai Bentuk Perlindungan Hukum TerhadapPerempuan’ (2019) 3 Lex Scientia Law Review.

HOW TO CITE: Tonic Tangkau, Prawitra Thalib, Daniel Julian Tangkau, Xavier Nugraha and Windy Agustin, 'Analysis on Non Muslim Heir Position Towards the Inheritance of Muslim Testator in Indonesia' (2020) 35 Yuridika. 